\title{
BIM Application to Select Appropriate Design Alternative with Consideration of LCA and LCCA
}

\author{
Young-su Shin and Kyuman Cho \\ Department of Architectural Engineering, Chosun University, 309 Pilmun-daero, Dong-gu, Gwangju 501-759, Republic of Korea
}

Correspondence should be addressed to Kyuman Cho; cho129@chosun.ac.kr

Received 27 March 2015; Accepted 10 June 2015

Academic Editor: Mohamed Marzouk

Copyright (C) 2015 Y.-s. Shin and K. Cho. This is an open access article distributed under the Creative Commons Attribution License, which permits unrestricted use, distribution, and reproduction in any medium, provided the original work is properly cited.

\begin{abstract}
Advancements in building materials and technology have led to the rapid development of various design solutions. At the same time, life cycle assessment (LCA) and life cycle cost analysis (LCCA) of such solutions have become areat burden to engineers and project managers. To help conduct LCA and LCCA conveniently, this study (i) analyzed the information needed to conduct LCA and LCCA, (ii) evaluated a way to obtain such information in an easy and accurate manner using a building information modeling tool, and (iii) developed an Excel spreadsheet-based framework that allowed for the simultaneous implementation of LCA and LCCA. The framework developed for LCA and LCCA was applied to a real building case to evaluate three possible alternatives for an external skin system. The framework could easily and accurately determine which skin system had good properties in terms of the LCA and LCCA performance. Therefore, these results are expected to assist in decision making based on the perspectives of economic and environmental performances in the early phases of a project, where various alternatives can be created and evaluated.
\end{abstract}

\section{Introduction}

During the planning, design, and construction of a building, cost management has traditionally been recognized as one of the most important decision-making factors for project participants in the construction industry. Cost planning in the planning and design phase of a project and monitoring and controlling in the construction phase of a project are very important management activities that can determine the success of a construction project. Over the last 10 years, consideration of the life cycle cost (LCC) to analyze the economic feasibility has been one of the greatest changes in the field of project cost management [1]. LCC analysis (LCCA) is most effective when it is conducted in the initial phases (i.e., planning and design phases) of a construction project. For this reason, project managers or engineers have analyzed the economic feasibility of various alternatives with a focus on the diverse elements of building, construction methods, and items [2].

In addition to considering the LCC concept, attention has been given to greenhouse gas (GHG) emissions in all industries around the globe. In particular, buildings are believed to have a considerable impact on the environment because they account for more than $39 \%$ of the total primary energy consumed and approximately $39 \%$ of the GHG emissions that occur in the United States [3]. Consequently, many studies have been conducted to both evaluate and reduce the GHG emissions that occur in the building production cycle. In particular, the methodology of life cycle assessment (LCA) is widely used. LCA is used to evaluate the GHG emissions throughout the entire process, including the material production, transport, assembly, operation, and demolition of a building. Just as with LCCA, LCA is effective when applied to the planning and design phases of a construction project. LCA evaluates GHG emissions based on a comparison of various alternatives as it focuses on the construction production system, including the materials and construction methods required in the early phase to complete the construction of a building [4].

LCA and LCCA have three major points in common: (i) their effects can be maximized if they are conducted in the early phase of a project, (ii) they can be conducted for a production system that includes all the elements of the building and construction methods, and (iii) they provide 
an analysis process that facilitates the selection of the optimal alternative by evaluating the economic and environmental performances of the alternatives $[2,4,5]$. On the other hand, it is difficult to apply the two techniques to buildings, compared to other "products," because of the following unique characteristics of construction projects: (i) buildings are large in size, with a wide variety of materials used in construction projects; (ii) there are a larger number of people involved in construction projects, and the demands of the project owner change frequently; and (iii) because each building is unique, the production system is less standardized compared to those for most other manufactured goods $[6,7]$.

Based on this background, this study was conducted to develop a method for improving the performance of LCA and LCCA utilizing the three-dimensional parametric building information modeling (BIM) approach.

This study was conducted using the following four steps. In step 1, a literature review was conducted to analyze the LCA and LCCA process and analysis methods, while simultaneously examining their limitations and problems. In step 2, the information and data required for LCA and the LCCA were analyzed based on the results from step 1 . The analysis led to (i) the information required to conduct both the LCA and LCCA and (ii) additional information that was required to utilize each technique. In step 3, the BIM was adopted as an approach to provide information and data for the LCA and LCCA implementations, which were analyzed in step 2. In addition, a spreadsheet-based framework, which compiled the information outflow from the BIM, was developed to conduct the LCA and LCCA simultaneously. In step 4, a case study, in which the developed framework was applied to a real building project, focused on identifying the applicability of the research output. The case study facilitated an in-depth analysis of the usefulness of the framework that was suggested in the present study.

\section{Step 1: State of the Art}

2.1. LCA. The LCA concept is generally accepted within the environmental research field. When applied to buildings, LCA encompasses the analysis and assessment of the environmental effects of building materials, components, and assemblies throughout the entire life of the building, including its construction, use, and demolition [8]. Because of the increase in the number of methods for LCA and examples of its use, international organizations such as the International Standard Organization (ISO) have worked on the standardization of LCA, which has resulted in the ISO 14040 series. In particular, ISO 14041 covers the "definition and inventory analysis of LCA" and is recognized as the standard for the LCA technique in many cases. According to ISO 14041, LCA could be applied in the following four steps. (i) The LCA goal and scope are defined to secure the reliability of the analysis results by clarifying the scope of the target product. (ii) A life cycle input-output inventory analysis is conducted to establish the life cycle inventory database (LCI DB), which contains a large volume of process and production data, including the raw material inputs, energy use, main product to coproducts ratio, production rates, and equivalent environmental releases. The unit process datasets form the basis of every LCI DB and the foundation of all LCA applications. A unit process dataset is obtained by quantifying the inputs and outputs in relation to a quantitative reference flow from a specific process. These inputs and outputs are generated from mathematical relationships based on the raw data. Consequently, a "unit process" is defined as the "smallest element considered in the life cycle inventory analysis" in ISO 14040. (iii) An environment impact assessment is performed based on the results of the inventory analysis, and (iv) the evaluated data is interpreted. LCA can be used in a variety of ways to manage an environmental load, compare alternatives, and establish environmental policy [9].

In the construction field, many studies have been conducted to evaluate the environmental performance based on LCA analysis. Hong et al. [3] suggested an integrated model for assessing the cost and $\mathrm{CO}_{2}$ emissions and calculated the $\mathrm{CO}_{2}$ emissions based on the strength of ready-mixed concrete. In another study, Hong et al. [10] introduced a green roof system with energy saving measures focusing on elementary schools in Seoul, South Korea, to analyze the cost and $\mathrm{CO}_{2}$ emissions. Khan et al. [11] developed decisionmaking methodology that integrated the LCA concept into risk analysis theory for identifying optimal plant design in the project early phase. Lee et al. [12] confirmed that the difference in $\mathrm{CO}_{2}$ emissions depended on the strength of the concrete according to the period of use. Cole [8] confirmed the difference in $\mathrm{CO}_{2}$ emissions using different major structural systems of buildings.

2.2. LCCA. LCCA is used to evaluate the economic feasibility based on the calculation of the equivalent values of all the important costs that occur within the life span, with particular focus on buildings or the major components of buildings [13]. An LCCA is conducted using the following four steps. (i) The analysis target is identified, which is the first step toward making a cost-effective decision by creating and evaluating the alternatives that can meet the minimum performance standards. (ii) The basic assumptions are established for the LCCA, including the analysis period and discount rate. In addition, the initial investment cost, operating cost, alteration/replacement cost, and other associated costs are confirmed, and the time of the occurrence of each cost is verified. Because these cost items occur at different points in time, it is important to convert each cost to the value at a single point in time. (iii) The LCC is calculated for each alternative by adding up the costs according to the type for each alternative. (iv) The related indices are calculated to evaluate the economic feasibility (the LCCA), including the net savings, savings-to-investment ratio, and payback period. In addition, a sensitivity analysis can be implemented to complement the LCCA methodology, which will provide reliability to the LCCA results.

Many previous studies have examined LCCA. Early studies on the LCC focused on minimizing the installation cost in the initial phases of building construction and maintenance, along with the replacement cost in the operation phase. Recently, attention has been given to studies on the energy cost in the operation phase, with the goal of evaluating 
the environmental performance of various materials and construction methods. For example, Uygunoğlu and Keçebaş [14] analyzed the energy saving performance in relation to the form and thickness of a concrete block and examined the payback period accordingly. Wong et al. [15] conducted an LCCA when green roof systems were used, which aimed at proving economic effects. Zhang and Wang [16] examined the economic performance of thermal power plants using LCCA. Chang et al. [17] used LCCA to analyze the waterconservation and energy saving effects of green roof systems and examined the cost-reduction effects of those systems. Akadiri et al. [18] developed an assessment model based on the use of diverse sustainable materials and suggested costreduction effects that could be attributed to the use of sustainable materials. Fu et al. [19] suggested a new algorithm for calculating the carbon emission in order to optimize building plans in terms of sustainability through comparing the five LCA tools.

\subsection{Integration of BIM into LCA and LCCA. While BIM def-} initions vary significantly according to the organization and researcher, the common concept is that the BIM is a program or process for extracting and reusing data by developing a model, which is presented in a multidimensional virtual space, using the data on the life cycle of a construction project $[20,21]$. Currently, BIM is used widely in the construction industry because of the following advantages: (i) a graphic user interface, which provides a work environment where the operator can observe the work visually, (ii) convenient modification and addition because object-based modeling can be performed, which leads to excellent design changes and alternative comparisons, and (iii) the production of diverse information with high usability. In other words, onetime modeling allows for the production of various design documents and quick and accurate quantity estimation for various alternatives [22].

Several previous studies on BIM have been conducted, but very few studies have been conducted that describe the integration of BIM into LCA and LCCA. Basbagill et al. [23] developed a combined BIM-LCA method to figure out which materials and superstructure designs could be effective in terms of $\mathrm{CO}_{2}$ emissions reduction according to BIM prescriptions for replacing materials in different types of structures. Consequently, it is possible to provide a method to help engineers select materials and superstructures appropriately during the early phases of a project. Han et al. [24] suggested an optimization method for building components that integrates genetic algorithms into the BIM approach, along with the LCCA result for each component. In this research, the BIM approach was utilized to calculate the energy consumption as a function of the installation of each component. Ristimäki et al. [25] developed a model for combining LCA and LCCA, in which a single energy system was adopted. This research demonstrated that the developed model was limited to a small part of a building, because of the difficulty in acquiring the data necessary to conduct the two analysis methods simultaneously. Iddon and Firth [26] analyzed $\mathrm{CO}_{2}$ emissions of a small dwelling house during the planning phase, where they utilized the BIM approach to consider various alternatives to building components, including structure and envelope systems. In the previous research referenced above, BIM has been used mostly to conveniently generate various design alternatives for conducting LCA or LCCA analysis, but there have been few ideas or theories on how BIM could not only be integrated to conduct LCA and LCCA, but also how to conduct them simultaneously.

2.4. Problem Statements. Given the increased focus on the economic and environmental performances of construction projects, most of the elements comprising projects have been considered in evaluations of their performances using LCA and LCCA. Despite this, the previous studies that were conducted had the following limitations. (i) The analyses were limited to a small number of design alternatives, because a large volume of data was needed to implement the LCA and LCCA. (ii) Some recycling of previous data was needed for each implementation of the LCA and LCCA because of the unique characteristics of construction projects. (iii) There has been little research focused on the application of the BIM approach for conducting LCA and LCCA simultaneously, for the purposes of reducing and recycling the information required for the two methods.

Based on this background and the identified problems, this paper proposes a method for efficiently performing LCA and LCCA, while reducing and recycling the information required for the two methods. This paper (i) identifies the information needed to conduct the LCA and LCCA (in step 2), (ii) shows how the information required for the two methods can be obtained conveniently using a BIM approach (in step 3), and (iii) demonstrates how the LCA and LCCA can be computed simultaneously, based on the developed framework, which incorporates the information obtained using the BIM approach (in step 3).

\section{Step 2: Identifying Data Required for Conducting LCA and LCCA}

As the first stage for developing a method that facilitates the LCA and LCCA implementation, in step 2, the information required for conducting the two methods was identified, along with each phase of the LCA and LCCA (i.e., construction, operation, and disposal) and the target activities of that phase, as listed in Table 1.

3.1. Required Data for LCA and LCCA in Construction Phase. According to the LCA methodology by the ISO, the target activities of the LCA in the construction phase of a building consist of the production, transport, and assembly of materials. According to Hong et al. [3], an examination of previous studies related to LCA showed that the environmental impact factors generated in the construction phase can generally be calculated using (1). As shown in this equation, the quantity of environmental emissions in the construction phase for system $A\left(\mathrm{EQ}_{A}^{\mathrm{Con}}\right)$ is the sum of the environmental impacts from the releases during production, transport, and assembly:

(1) Environmental emissions in the production process: if system $A$ consists of $i$ materials, the environmental 
TABLE 1: Data required for conducting LCA and LCCA.

\begin{tabular}{|c|c|c|c|c|c|c|c|}
\hline \multirow{2}{*}{ Life cycle phase } & \multirow{2}{*}{$\begin{array}{l}\text { Target activities for conducting } \\
\text { LCA and LCCA }\end{array}$} & \multicolumn{3}{|c|}{ Required information for LCA } & \multicolumn{3}{|c|}{ Required information for LCC } \\
\hline & & Q & $\mathrm{EF}$ & Additions & Q & UC & Additions \\
\hline \multirow{3}{*}{ Construction } & Manufacturing factory & $\bullet$ & $\bullet$ & - & & & (i) Unit cost, including labor and \\
\hline & Transporting & $\bullet$ & $\bullet$ & (i) Fuel type & $\bullet$ & $\bullet$ & equipment costs. It can be found \\
\hline & Assembling site & $\bullet$ & 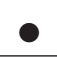 & (ii) Fuel consumptions & & & using RS Means data \\
\hline \multirow[t]{3}{*}{ Operation } & Maintenance and repair & $\bullet$ & $\bullet$ & $\begin{array}{l}\text { (i) Operation period } \\
\text { (ii) Repair cycle } \\
\text { (iii) Repair rate }\end{array}$ & $\bullet$ & $\bullet$ & $\begin{array}{l}\text { (i) Operation period } \\
\text { (ii) Repair cycle } \\
\text { (iii) Repair rate }\end{array}$ \\
\hline & Replacement & $\bullet$ & $\bullet$ & (i) Replacement cycle & $\bullet$ & $\bullet$ & (i) Replacement cycle \\
\hline & Operating & & $\bullet$ & (i) Energy consumption & & $\bullet$ & (i) Energy consumption \\
\hline Disposal & Disposal & $\bullet$ & $\bullet$ & $\begin{array}{l}\text { (i) Fuel type } \\
\text { (ii) Fuel consumptions }\end{array}$ & $\bullet$ & $\bullet$ & (i) Unit cost for disposal \\
\hline
\end{tabular}

${ }^{*} \mathrm{Q}=$ quantity of materials, $\mathrm{EF}=$ emission factor, and $\mathrm{UC}=$ unit cost.

impacts generated in the production process can be calculated by multiplying the quantity of each material $\left(Q_{a}^{M}\right)$ and the emission factor of the environmental release when manufacturing that material $\left(\mathrm{EF}_{a}^{M}\right)$. In general, the emission factor of each material can be referred from the LCI DB of the countries.

(2) Environmental emissions in the transport process: if manufactured materials are transported to the construction site by $j$ number of vehicles, the environmental impacts can be calculated by multiplying the quantity of each vehicle $\left(Q_{b}^{V}\right)$ by the emission factor of the environmental release of that vehicle $\left(\mathrm{EF}_{b}^{V}\right)$.

(3) Environmental emissions in the assembly process on site: if $k$ number of the equipment is used to assemble the materials at the construction site, the environmental impacts can be calculated by multiplying the quantity of equipment $\left(Q_{c}^{E}\right)$ by the emission factor of the environmental release of the individual pieces of equipment $\left(\mathrm{EF}_{b}^{E}\right)$.

(4) To determine the emission factors of the transport vehicles and installation equipment, (i) the fuel type (i.e., gasoline, diesel, etc.) for each vehicle and piece of equipment for conducting the work should first be identified, and then (ii) the emission factors, along with the fuel type, can be found by referring to the LCI DB [27].

(5) With consideration of the above environmental impacts in each element, the amount of environmental emissions in the construction phase can be calculated using

$$
\begin{aligned}
\mathrm{EQ}_{A}^{\text {Con }}= & \sum_{a=1}^{i}\left(Q_{a}^{M} \times \mathrm{EF}_{a}^{M}\right)+\sum_{b=1}^{j}\left(Q_{b}^{V} \times \mathrm{EF}_{b}^{V}\right) \\
& +\sum_{c=1}^{k}\left(Q_{c}^{E} \times \mathrm{EF}_{c}^{E}\right),
\end{aligned}
$$

where $\mathrm{EQ}_{A}^{\text {Con }}=$ the quantity of environmental emissions in the construction phase for system $A$,
$Q_{a}^{M}=$ the quantity of material $a$ comprising system $A, \mathrm{EF}_{a}^{M}=$ the emission factor of the environmental release while manufacturing material $a, Q_{b}^{V}=$ the number of vehicles used to transport material $b$, $\mathrm{EF}_{b}^{V}=$ the emission factor of the vehicle used for material $b, Q_{c}^{E}=$ the pieces of installation equipment, and $\mathrm{EF}_{c}^{E}=$ the emission factor of the equipment.

Generally, according to Dell'Isola and Kirk [13], the costs of items in the construction phase to conduct the LCCA can be calculated using (2). If system $A$ would consist $i$ of materials, the installation costs of system $A\left(C_{A}^{\text {Ins }}\right)$ can be determined by multiplying the quantity of each material in the system by the installation cost of a unit area (i.e., unit cost). The unit cost generally refers to reported data such as from RS Means. Thus, such data includes the labor cost and equipment cost per unit area:

$$
C_{A}^{\mathrm{Ins}}=\sum_{a=1}^{i}\left(Q_{a}^{M} \times \mathrm{UC}_{a}\right),
$$

where $C_{A}^{\text {Ins }}=$ the installation cost of system $A, Q_{a}^{M}=$ the quantity of material $a$ comprising system $A$, and $\mathrm{UC}_{a}=$ the unit cost for installing material $a$ (i.e., $\$ / \mathrm{m}^{2}$ ).

As described above and listed in Table 1, to conduct the LCA and LCCA in the construction phase, it is necessary to obtain the following information: (i) the quantity of each material in the targeted system and the quantity of each set of equipment for transportation and installation, (ii) the emission factor of each material and piece of equipment, and (iii) additional information such as the fuel type and fuel consumption of equipment, as well as the unit installation cost.

\subsection{Required Data for LCA and LCCA in Operation Phase.} The target activities of the LCA in the building operation phase consist of maintenance and repair (M\&R), replacement, and operation. According to previous studies, the quantity of environmental emissions generated during the operation phase can be calculated as follows [28]:

(1) Environmental impacts for M\&R and replacement: these can be calculated in the same manner as 
the environmental impacts during the construction phase. Along with the expected occurrence times for the replacement and M\&R of the system, environmental impacts can be calculated considering the quantity and emission factors of the material, transport vehicle, and installation equipment.

(2) Environmental impacts during operation: these are calculated by multiplying (i) the annual quantity of energy consumption $\left(Q_{a}^{E}\right)$ for each type (i.e., heating, air-conditioning, appliance, etc.) needed for the operation of buildings, (ii) the emission factors of environmental release depending on the energy type $\left(\mathrm{EF}_{a}^{E}\right.$ ), and (iii) the period in operation $(n)$ (refer to (3)):

$$
\mathrm{EQ}_{A}^{O}=\left(Q_{a}^{E} \times \mathrm{EF}_{a}^{E}\right) \times n,
$$

where $\mathrm{EQ}_{A}^{\mathrm{O}}=$ the quantity of environmental emissions during the operation phase for system $A, Q_{a}^{E}=$ the annual energy consumption of the system, $\mathrm{EF}_{a}^{E}=$ the emission factor of environmental release depending on the energy type, and $n=$ the period in operation.

The LCCA during the operation phase includes the M\&R and energy costs, which can be calculated using (4) and (5), respectively:

(1) Maintenance, repair and replacement costs $\left(C_{A}^{\mathrm{MR}}\right)$ : along with the expected occurrence times of the $M \& R$ and the replacement of the system, the costs are calculated by multiplying (i) the quantity of each item $\left(Q_{d}^{\mathrm{MR}}\right)$ in system $A$ that requires maintenance, repair, and replacement by (ii) the unit cost $\left(\mathrm{UC}_{d}^{\mathrm{MR}}\right)$ for such target activities. Moreover, because M\&R and replacement costs will be incurred in the future, the equivalent present worth of the costs discounted at the interest rate (DR) for the M\&R and replacement time $\left(T_{d}\right)$ should be considered (please refer to [13] for the details):

$$
C_{A}^{\mathrm{MR}}=\sum_{d=1}^{l}\left(\mathrm{Q}_{d}^{\mathrm{MR}} \times \mathrm{UC}_{d}^{\mathrm{MR}} \times \frac{1}{(1+\mathrm{DR})^{T_{d}}}\right)
$$

where $C_{A}^{\mathrm{MR}}=$ the present worth of total M\&R and replacement costs of system $A, Q_{d}^{\mathrm{MR}}=$ the quantity of each item comprising the system that requires $M \& R$ and replacement, $\mathrm{UC}_{d}^{\mathrm{MR}}=$ the unit cost for $\mathrm{M} \& \mathrm{R}$ and replacement, $\mathrm{DR}=$ the discount rate, and $T_{d}=$ the $\mathrm{M} \& \mathrm{R}$ and replacement time of each item.

(2) The operation energy cost $\left(C_{A}^{E}\right)$ is the product of the quantity of annual energy consumption $\left(Q_{a}^{E}\right)$ and the unit cost of the energy source $\left(\mathrm{UC}^{E}\right)$. Moreover, because the cost is a future cost that occurs annually, the discount rate (DR) for the operation period $(n)$ is considered to convert the cost to an equivalent present value in total (please refer to [13] for the details):

$$
C_{A}^{E}=\left(Q_{a}^{E} \times \mathrm{UC}^{E}\right) \times \frac{(1+\mathrm{DR})^{n}-1}{\mathrm{DR}(1+\mathrm{DR})^{n}},
$$

where $C_{A}^{E}=$ the present worth of total energy cost of system $A$ during $n$ years, $Q_{a}^{E}=$ the annual energy consumption of the system, $\mathrm{UC}^{E}=$ the unit cost of the energy source, and $n=$ the period in operation.

As described above and listed in Table 1, to conduct the LCA and LCCA during the operation phase, it is essential to obtain (i) the quantity information, (ii) information on the emission factor, and (iii) additional information such as information on the $M \& R$ and replacement (i.e., operation period, repair cycle, repair rate, replacement rate, etc.) and information on the energy (i.e., energy consumption and energy cost).

3.3. Required Data for LCA and LCCA in Disposal Phase. During the disposal phase of the building, the LCA and LCCA can be conducted based on (6) and (7), respectively [28]. The quantity of environmental emissions during the disposal $\left(\mathrm{EQ}_{A}^{D}\right)$ can be calculated considering the quantity of the disposal equipment $\left(Q_{e}^{\mathrm{ED}}\right)$ and the emission factor according to the energy type of the individual pieces of equipment $\left(\mathrm{EF}_{e}^{\mathrm{ED}}\right)$ (refer to (6)). Therefore,

$$
\mathrm{EQ}_{A}^{D}=\sum_{e=1}^{m}\left(Q_{e}^{\mathrm{ED}} \times \mathrm{EF}_{e}^{\mathrm{ED}}\right)
$$

The disposal cost $\left(C_{A}^{D}\right)$ can be calculated by multiplying the disposal quantity $\left(Q_{A}^{D}\right)$ by the unit cost $\left(U_{C}^{D}\right)$ for the disposal work. Similar to the M\&R cost, the disposal cost needs to be converted to an equivalent present cost discounted at a certain interest rate (DR) for the time of the disposal $\left(T_{d}\right)$, because the cost will be incurred in the future (refer to (7)). Therefore,

$$
C_{A}^{D}=Q_{A}^{D} \times \mathrm{UC}_{A}^{D} \times \frac{1}{(1+\mathrm{DR})^{T_{d}}} .
$$

As described above and listed in Table 1, the following are needed to conduct the LCA and LCCA during the disposal phase: (i) the quantity information, (ii) information on the emission factor, and (iii) additional information such as the fuel type and consumption of the equipment and unit cost for disposal.

3.4. Required Data for LCA and LCCA. As analyzed in this step, a large amount of information is needed to conduct the LCA and LCCA, which makes project managers hesitant to apply these techniques. In addition, even if they are used, it is difficult to apply them to a range of alternatives. Therefore, this study developed a method to overcome the problems associated with conducting LCA and LCCA based on "easiness of data acquisition" and "data recycling." This 
section identifies the data required for LCA and LCCA, along with the project phase, and then classifies the data into two categories: (i) the data commonly required and (ii) additional data, as listed in Table 1.

\section{Step 3: Framework for Conducting LCA and LCCA}

In step 3, a framework for the LCA and LCCA was developed using the following process: (i) mapping between the required LCA and LCCA data analyzed in step 2 and the acquirable data from BIM and (ii) embodying the calculation methods (Equations (1) to (7)) and all the data needed for LCA and LCCA into an Excel spreadsheet-based framework.

4.1. Mapping Required Data for LCA and LCCA with BIM Data. Despite some differences between the different types of BIM software, the application of BIM generally facilitates the acquisition of the following data: (i) visual model data expressed in a three-dimensional space, (ii) information on a quantity estimation, (iii) information on the necessary energy consumption to operate a building through an energy simulation, and (iv) information on construction interference among work activities [29].

As listed in Table 1, it is important to obtain diverse information to conduct the LCA and LCCA. Therefore, mapping can be performed as follows between the data that can be obtained from the BIM and the information that is required to conduct the LCA and LCCA:

(i) Quantity information about the material resources for each alternative: as listed in Table 1, the basic data to conduct the LCA and LCCA are information on the quantity of the input resource for each life cycle of the building. Among such diverse quantity information, information about the quantity of materials used to form the relevant building is fundamental to conducting the LCA and LCCA. This is because information about the quantity of materials has the greatest influence on making a decision based on the results of the LCA and LCCA in the construction and operation phases. Such information about the quantity of materials can be readily obtained from BIM. Furthermore, information about the quantities of materials for various alternatives can be obtained in a convenient and accurate way in the feasibility phase of a project, in which the level of change in the design plan can be significant.

(ii) Energy consumption: considering the recent trend of using many energy saving techniques, energy consumption is the most important factor among the factors that affect the results of the LCA and LCCA in the operation phase of a building. If the BIM is used in the operation phase, it is possible to obtain information on the energy consumption in a case where various energy saving techniques are applied.
In addition to a building information model of a particular building, information on the following building conditions is required for analyzing the building's energy consumption: its location, azimuthal angle, climate condition, mechanical systems, and thermal conductivity performance. Once these conditions have been established, the BIM software can calculate the energy consumption of the building, expressed by parameters such as the monthly energy balance.

In the delivery process for an environmentally friendly building, the following aspects have recently become important great issues: (i) information about the quantity of materials and data on the energy consumption are the most fundamental for conducting the LCA and LCCA for various design alternatives, depending on the application of energy saving techniques; and (ii) the convenient acquisition of such core data from the BIM can be a great benefit when the LCA and LCCA are implemented in the delivery process for an environmentally friendly building.

In the meantime, the remaining data listed in Table 1 (i.e., the LCI DB, machinery data, operation period, etc.) can be obtained based on the existing methodologies for the LCA and LCCA.

4.2. Framework for Conducting LCA and LCCA Using BIM. Because the data obtained from BIM are readily compatible with an Excel spreadsheet, the framework was established using the spreadsheet program, in which the LCA and LCCA implementation methods are automatically connected to each other. As shown in Figures 1 through 4, the framework consists of four sheets in total, including three sheets for conducting the LCA and LCCA in the construction phase, operation phase, and disposal phase and one sheet for summarizing the results from these three sheets. Meanwhile, the data on each sheet can be entered manually after it has been extracted automatically using BIM.

4.2.1. Worksheet for Construction Phase. As shown in Figure 1, cell lines 1 to 6 on the sheet represent the quantity information that is commonly required to conduct the LCA and LCCA for the system, which was extracted automatically using the BIM. In other words, cell lines 1 and 2 show the material information for each system, whereas cell lines 3 to 6 present the quantity information for each material, including the weight (i.e., cell line 3 ) and the equivalent volume (i.e., cell line 4), area (i.e., cell line 5), and length values (i.e., cell line 6) corresponding to this weight.

Cell lines 7 to 25 are used for inputting the information that is needed to conduct the LCA for the equipment that is used in manufacturing (cell lines 10 to 17), transport, and construction (cell lines 22 to 25). In addition, (i) the fuel type of the input equipment and vehicles for material manufacture, transport, and construction (i.e., electricity, diesel, and gasoline) and (ii) the capacity of the equipment and vehicles (i.e., $\mathrm{kg} / \mathrm{EA}, \mathrm{m}^{3} / \mathrm{EA}, \mathrm{m}^{2} / \mathrm{EA}$, and $\mathrm{m} / \mathrm{EA}$ ) make it possible to calculate the required amount of fuel for the equipment and vehicles for the manufacture, transport, and construction (i.e., cell lines 18 and 26). Subsequently, the emission factors 


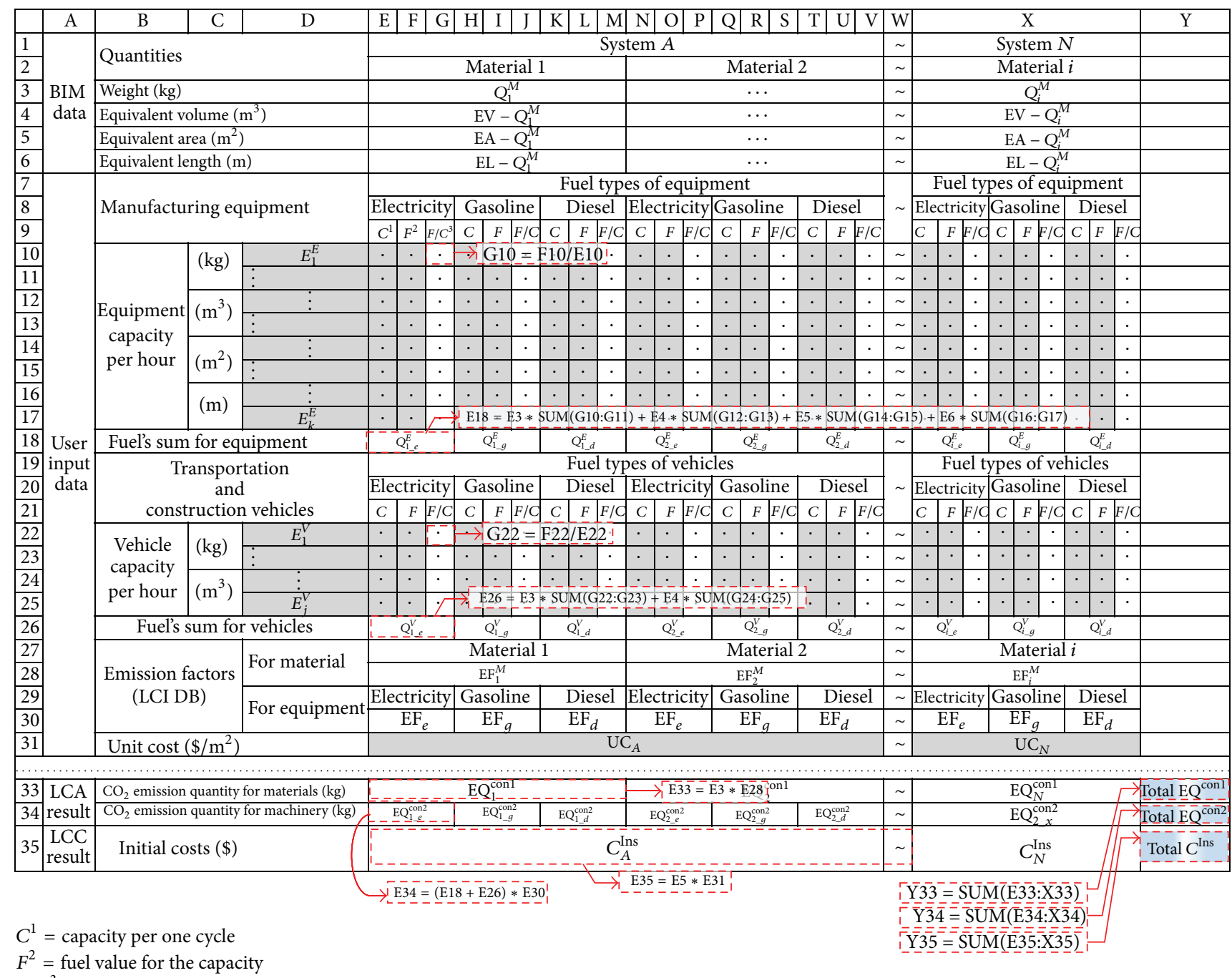

$F / C^{3}=$ resource per unit capacity

FIGURE 1: Worksheet for LCA and LCC analysis in construction phase.

according to the type of material and equipment from the LCI $\mathrm{DB}$ (cell lines 27 to 30 ) are used to calculate the $\mathrm{CO}_{2}$ emission quantity for materials and machinery (cell lines 33 and 34). To calculate the construction costs comprising the LCC, it is necessary to input the unit cost (cell line 31) of each system, which can be provided by RS Means, and so forth.

4.2.2. Worksheets for Operation and Disposal Phases. As shown in Figure 2 and (3) to (5), the material quantities and energy requirements per year, which can be extracted by the BIM program, are used to conduct the LCA and LCCA in the operation phase. Based on this information and program, if a user enters (i) the electricity price (i.e., cell (D7) in Figure 2), (ii) unit cost (i.e., adopted from the sheet "construction phases," cell (E31) in Figure 1), and (iii) operation information per system (i.e., cells (D9) to (D15) in Figure 2), they can automatically obtain the LCA and LCCA results in the operation phase.

The LCA and LCCA in the disposal phase are performed in a manner similar to that in the construction phase. They are also conducted based on the input values for the equipment used to demolish buildings (refer to Figure 3).

4.2.3. Worksheet for Summary. This sheet includes the results corresponding to "Total " on sheets 1 to 3 above (i.e., line 33, line 34 , and line 35 of column Y on sheet 1 ; line 19, line 20, and line 21 of column L on sheet 2; and line 16 and line 17 of column Y on sheet 3 ) (refer to Figure 4).

\section{Step 4: Case Application}

A case application was conducted to verify the usability of the developed framework and the methodologies for conducting the LCA and LCCA. The following presents an overview of the building project selected for the application:

(i) Location: 868-4 Hak-dong, Dong-gu, Gwangju, Republic of Korea.

(ii) Structural system: steel-reinforced concrete structure. 


\begin{tabular}{|c|c|c|c|c|c|c|c|c|c|c|c|c|}
\hline & A & B & $\mathrm{C}$ & $\mathrm{D}$ & $\mathrm{E}$ & $\mathrm{F}$ & G & $\mathrm{H}$ & I & $\mathrm{J}$ & $\mathrm{K}$ & $\mathrm{L}$ \\
\hline 1 & \multirow{6}{*}{$\begin{array}{r}\text { BIM } \\
\text { data }\end{array}$} & \multirow{2}{*}{\multicolumn{2}{|c|}{ Quantities }} & \multicolumn{6}{|c|}{ System $A$} & $\sim$ & System $N$ & \\
\hline 2 & & & & \multicolumn{3}{|c|}{ Material 1} & \multicolumn{3}{|c|}{ Material 2} & $\sim$ & Material $i$ & \\
\hline 3 & & \multicolumn{2}{|c|}{ Equivalent area $\left(\mathrm{m}^{2}\right)$} & \multicolumn{3}{|c|}{$\mathrm{EA}-\mathrm{Q}_{1}^{M}$} & \multicolumn{3}{|c|}{$\ldots$} & $\sim$ & $\mathrm{EA}-\mathrm{Q}_{i}^{M}$ & \\
\hline 4 & & \multirow{3}{*}{$\begin{array}{c}\text { Energy } \\
\text { simulation }\end{array}$} & Source & \multicolumn{5}{|c|}{ Electricity } & & 少 & 'v' & \\
\hline 5 & & & Energy type & Heating & \begin{tabular}{|c|} 
Hot-water \\
supply
\end{tabular} & Air-conditioning & $\begin{array}{c}\text { Ventilation } \\
\text { fan }\end{array}$ & Appliance & & 乲 & & \\
\hline 6 & & & \begin{tabular}{|c|}
$\begin{array}{c}\text { Energy requirement } \\
(\mathrm{MWh} / \mathrm{yr})\end{array}$ \\
\end{tabular} & $\mathrm{ER}_{\mathrm{H}}$ & $\mathrm{ER}_{\mathrm{HW}}$ & $\mathrm{ER}_{\mathrm{AC}}$ & $\mathrm{ER}_{\mathrm{V}}$ & $\mathrm{ER}_{\mathrm{A}}$ & & 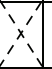 & & \\
\hline 7 & \multirow{11}{*}{\begin{tabular}{|c} 
User \\
input \\
data \\
\\
\end{tabular}} & \multicolumn{2}{|c|}{ Electricity price $(\$ / \mathrm{MWh})$} & \multicolumn{5}{|c|}{$\mathrm{UC}^{E}$} & 产 & 不 & 谷 & \\
\hline 8 & & \multicolumn{2}{|c|}{ Unit $\operatorname{cost}^{1}\left(\$ / \mathrm{m}^{3}\right)$} & \multicolumn{6}{|c|}{$\mathrm{UC}_{A}$} & $\sim$ & $\mathrm{UC}_{N}$ & \\
\hline 9 & & & Replacement term (yr) & \multicolumn{6}{|c|}{$\cdots$} & $\sim$ & $\cdots$ & \\
\hline 10 & & & Maintenance term (yr) & \multicolumn{6}{|c|}{$\cdots$} & $\sim$ & $\cdots$ & \\
\hline 11 & & & Maintenance rate (\%) & \multicolumn{6}{|c|}{$\cdots$} & $\sim$ & $\cdots$ & \\
\hline 12 & & $\begin{array}{l}\text { Operate } \\
\text { information }\end{array}$ & Study period $(\mathrm{yr})$ & \multicolumn{6}{|c|}{$\cdots$} & $\sim$ & $\cdots$ & \\
\hline 13 & & & \begin{tabular}{|l|} 
Number of replacement times \\
\end{tabular} & \multicolumn{6}{|c|}{$\cdots$} & $\sim$ & $\Rightarrow \mathrm{D} 16=\mathrm{D} 3 * \mathrm{D} 8$ & \\
\hline 14 & & & Number of maintenance times & \multicolumn{6}{|c|}{$\cdots$} & $\sim$ & & \\
\hline 15 & & & Discount rate $(\%)$ & \multicolumn{6}{|c|}{$\cdots$} & $\sim$ & $\mathrm{D} 17=(\mathrm{D} 3 * \mathrm{D} 8) *$ & $111_{-}$ \\
\hline 16 & & Replaceme & ent cost (\$) & \multicolumn{6}{|c|}{$\mathrm{UC}_{A}^{\mathrm{MR} 1}$} & $\sim$ & $\mathrm{UC}_{N}^{\mathrm{MR} 1}$ & \\
\hline 17 & & Maintenan & nce cost $(\$)$ & \multicolumn{6}{|c|}{$\mathrm{UC}_{A}^{\mathrm{MR} 2}$} & $\sim$ & $\mathrm{UC}_{N}^{\mathrm{MR} 2}$ & \\
\hline & & & & & ... & 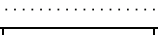 & 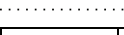 & & & $\cdots$ & & \\
\hline 19 & $\begin{array}{l}\text { LCA } \\
\text { result }\end{array}$ & \multicolumn{2}{|c|}{\begin{tabular}{|l|}
$\mathrm{CO}_{2}$ emission quantity \\
during operation phase $(\mathrm{kg} / \mathrm{yr})$
\end{tabular}} & $\mathrm{EQ}_{\mathrm{H}}^{E}$ & $\mathrm{EQ}_{\mathrm{HW}}^{E}$ & $\mathrm{EQ}_{\mathrm{AC}}^{E}$ & $\mathrm{EQ}_{\mathrm{V}}^{E}$ & $\mathrm{EQ}_{\mathrm{A}}^{E}$ & & ' & 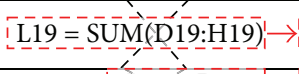 & Total $\mathrm{EQ}_{-}^{\bar{E}}$ \\
\hline 20 & \multirow{2}{*}{$\begin{array}{l}\text { LCC } \\
\text { result }\end{array}$} & \multicolumn{2}{|c|}{ Energy costs $(\$)$} & \multicolumn{5}{|c|}{$C^{E}$} & & 水 & $\begin{array}{l}\mathrm{L} 20=\mathrm{D} 20 \\
\mathrm{H}\end{array}$ & Total_ $C_{-}^{\bar{E}}$ \\
\hline 21 & & \multicolumn{2}{|c|}{ R\&M costs $(\$)$} & \multicolumn{6}{|c|}{$\mathrm{C}_{\mathrm{A}}^{\mathrm{MR}}$} & $\sim$ & 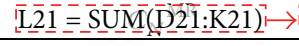 & Total $C_{-}^{\mathrm{MR}}$ \\
\hline
\end{tabular}

Unit $\operatorname{cost}^{1}$ = adopter from the sheet for "construction phase"

$$
\begin{array}{rl}
\mathrm{D} 21 & \mathrm{D} 16 /(1+\mathrm{D} 15) \wedge(\mathrm{D} 9 * \mathrm{D} 13)+\mathrm{D} 17 /(1+\mathrm{D} 15) \wedge(\overline{\mathrm{D}} 10 * \mathrm{D} 14)+\cdots \\
\mathrm{D} 20=(\mathrm{SUM}(\mathrm{D} 6: \mathrm{H} 6) * \mathrm{D} 7) *((1+\mathrm{D} 15) \wedge \mathrm{D} 12-\overline{1}) /(\mathrm{D} 15 *(1+\mathrm{D} 15) \wedge \mathrm{D} 12)
\end{array}
$$

\begin{tabular}{|c|c|c|c|c|c|c|c|c|c|c|c|c|c|c|c|}
\hline & A & B & $\mathrm{C}$ & $\mathrm{D}$ & $\mathrm{F}$ & \begin{tabular}{l|l|}
$\mathrm{H}$ & $\mathrm{I}$ \\
\end{tabular} & \begin{tabular}{l|l|l|}
$\mathrm{K}$ & $\mathrm{L}$ & $\mathrm{M}$ \\
\end{tabular} & \begin{tabular}{|l|l|l|}
$\mathrm{N}$ & $\mathrm{O}$ & $\mathrm{P}$ \\
\end{tabular} & \begin{tabular}{l|l|l}
$\mathrm{Q}$ & $\mathrm{R}$ & $\mathrm{S}$
\end{tabular} & \begin{tabular}{l|l|l}
$\mathrm{T}$ & $\mathrm{U}$ & $\mathrm{V}$
\end{tabular} & $\mathrm{W}$ & \multicolumn{3}{|c|}{$\mathrm{X}$} & Y \\
\hline 1 & \multirow{4}{*}{$\begin{array}{r}\text { BIM } \\
\text { data }\end{array}$} & \multirow{2}{*}{\multicolumn{3}{|c|}{ Quantities }} & \multicolumn{6}{|c|}{ System $A$} & $\sim$ & \multirow{2}{*}{\multicolumn{3}{|c|}{$\begin{array}{l}\text { System } N \\
\text { Material } i\end{array}$}} & \\
\hline 2 & & & & & \multicolumn{3}{|c|}{ Material 1} & \multicolumn{3}{|c|}{ Material 2} & $\sim$ & & & & \\
\hline 3 & & \multicolumn{3}{|c|}{ Weight (kg) } & \multirow{2}{*}{\multicolumn{3}{|c|}{$\frac{Q_{1}^{M}}{E V-Q_{1}^{M}}$}} & & & & $\sim$ & \multicolumn{3}{|c|}{$Q_{i}^{M}$} & \\
\hline 4 & & \multicolumn{3}{|c|}{ Equivalent volume $\left(\mathrm{m}^{3}\right)$} & & & & & \multicolumn{2}{|l|}{$\cdots$} & $\sim$ & \multicolumn{3}{|c|}{$\mathrm{EV}-\mathrm{Q}_{i}^{M}$} & \\
\hline 5 & \multirow{10}{*}{ 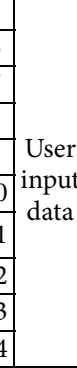 } & \multicolumn{3}{|c|}{ Disposal cost $(\$ / \mathrm{kg})$} & \multicolumn{6}{|c|}{$\mathrm{UC}_{A}^{D}$} & $\sim$ & \multicolumn{3}{|c|}{$\mathrm{UC}_{\mathrm{N}}^{D}$} & \\
\hline 6 & & \multirow{2}{*}{\multicolumn{3}{|c|}{\begin{tabular}{|c|l|} 
Operate & Study period (yr) \\
\cline { 2 - 3 } & Discount rate (\%) \\
\end{tabular}}} & & & $\cdots$ & & & & $\sim$ & \multicolumn{3}{|c|}{$\cdots$} & \\
\hline 7 & & & & & \multicolumn{6}{|c|}{$\cdots$} & $\sim$ & & $\cdots$ & & \\
\hline 8 & & \multirow{3}{*}{\multicolumn{3}{|c|}{ Disposal equipment }} & \multicolumn{6}{|c|}{ Fuel types of equipment } & \multicolumn{4}{|c|}{\begin{tabular}{|l} 
Fuel types of equipment \\
\end{tabular}} & \\
\hline 9 & & & & & Electricity & Gasoline & Diesel & Electricity & Gasoline & Diesel & $\sim$ & \multicolumn{3}{|c|}{\begin{tabular}{|l|l|l|} 
Electricity & Gasoline & Diesel \\
\end{tabular}} & \\
\hline 10 & & & & & \begin{tabular}{|l|l|l|}
$C^{1}$ & $F^{2}$ & $F / C^{3}$ \\
\end{tabular} & \begin{tabular}{|l|l|l|}
$C$ & $F$ & $F / C$ \\
\end{tabular} & \begin{tabular}{l|l|l|}
$C$ & $F$ & $F / C$ \\
\end{tabular} & \begin{tabular}{|l|l|l|}
$C$ & $F$ & $F / C$ \\
\end{tabular} & \begin{tabular}{l|l|l|}
$C$ & $F$ & $F / C$ \\
\end{tabular} & \begin{tabular}{l|l|l|}
$C$ & $F$ & $F / C$ \\
\end{tabular} & & \begin{tabular}{|l|l|l|}
$C$ & $F$ & $F / C$ \\
\end{tabular} & \begin{tabular}{l|l|l|l|} 
& $C$ & $F$ & $F / C$ \\
\end{tabular} & \begin{tabular}{|l|l|l|}
$C$ & $F$ & $F / C$ \\
\end{tabular} & \\
\hline 11 & & \begin{tabular}{|c|}
$\begin{array}{c}\text { Equipmentent } \\
\text { capacity } \\
\text { per hour }\end{array}$ \\
\end{tabular} & $\left(\mathrm{m}^{3}\right)$ & $E_{\mathrm{m}}^{\mathrm{ED}}$ & \begin{tabular}{l|l|l|}
. &. & 0
\end{tabular} & $\begin{array}{r}\mathrm{G} 11=\mathrm{F} \\
\sqrt{\mathrm{E}}=\mathbf{1}=\overline{\mathrm{E}}\end{array}$ & $\begin{array}{l}11 / \mathrm{E} 11 \\
\overline{4}=* \overline{\mathrm{G}} \overline{1}\end{array}$ & $\cdot$ & . & $\cdot \cdot \cdot$ & $\sim$ & $\cdot \cdot$ & \begin{tabular}{|l|l|l|}
$\cdot$ &. &. \\
\end{tabular} & $\cdot \cdot \cdot \cdot$ & \\
\hline 12 & & \multicolumn{3}{|c|}{\begin{tabular}{|l|} 
Fuel's sum for equipment \\
\end{tabular}} & $\mathrm{Q}_{1 \_e}^{\mathrm{ED}^{-}}=-1$ & $\mathrm{Q}_{1-g}^{-}-$ & $--\mathrm{Q}_{1-d}^{-1}$ & $\mathrm{Q}_{2 \_e}^{\mathrm{ED}}$ & $\mathrm{Q}_{2-g}^{\mathrm{ED}}$ & $\mathrm{Q}_{2 \_d}^{\mathrm{ED}}$ & $\sim$ & $\mathrm{Q}_{i_{e}}^{\mathrm{ED}}$ & $\mathrm{Q}_{i_{-g}}^{\mathrm{ED}}$ & $\mathrm{Q}_{i-d}^{\mathrm{ED}}$ & \\
\hline 13 & & Emission & & For & Electricity & Gasoline & Diesel & Electricity & Gasoline & Diesel & $\sim$ & Electricity & y Gasoline & Diesel & \\
\hline 14 & & factors (LCI & & equipment & $\mathrm{EF}_{e}$ & $\mathrm{EF}_{g}$ & $\mathrm{EF}_{d}$ & $\mathrm{EF}_{e}$ & $\mathrm{EF}_{g}$ & $\mathrm{EF}_{d}$ & $\sim$ & $\mathrm{EF}_{e}$ & $\mathrm{EF}_{g}$ & $\mathrm{EF}_{d}$ & \\
\hline 16 & \begin{tabular}{|l|} 
LCA \\
result \\
\end{tabular} & $\begin{array}{l}\mathrm{CO}_{2} \text { emis } \\
\text { for machir }\end{array}$ & sion & $\begin{array}{l}\text { quantity } \\
\text { (kg) }\end{array}$ & $\mid$ & $\begin{array}{ll}\mathrm{EQ}_{1_{-} g}^{\mathrm{ED}} \\
:\end{array}$ & $\mathrm{EQ}_{1 \_d}^{\mathrm{ED}}$ & $\mathrm{EQ}_{2 \_e}^{\mathrm{ED}}$ & $\mathrm{EQ}_{2}^{\mathrm{ED} g}$ & $\mathrm{EQ}_{2 \_d}^{\mathrm{ED}}$ & $\sim$ & & $\mathrm{EQ}_{i \_x}^{\mathrm{ED}}$ & & Total EQ $\mathrm{EQ}$ \\
\hline 17 & \begin{tabular}{|l|}
$\mathrm{LCC}$ \\
result
\end{tabular} & Disposal c & costs & & & & $C_{A}^{D}$ & & & & $\sim$ & & $C_{N}^{D}$ & & Total $\bar{C}^{\bar{D}}$ \\
\hline
\end{tabular}

FIgURE 2: Worksheet for LCA and LCC analysis during operation phase.

$C^{1}=$ capacity per one cycle

$F^{2}$ = fuel value for the capacity

$F / C^{3}=$ resource per unit capacity

FIGURE 3: Worksheet for LCA and LCC analysis in disposal phase. 


\begin{tabular}{|c|c|c|c|}
\hline & A & B & C \\
\hline 1 & Phase Assessment & $\mathrm{LCCO}_{2}$ & LCC \\
\hline 2 & \multirow{2}{*}{ Construction } & 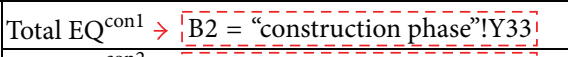 & \multirow{2}{*}{ Total $C^{\text {Ins }} \longrightarrow \mathrm{C}_{\mathrm{C}}^{\mathrm{C} 2}=$ "construction phase"! $\mathrm{Y} 35$} \\
\hline 3 & & Total $\mathrm{EQ}^{\mathrm{con} 2} \rightarrow \mathrm{B} 3=$ "construction phase"!Y 34 & \\
\hline 4 & \multirow{2}{*}{ Operation } & \multirow{2}{*}{ Total $\mathrm{EQ}^{E} \longrightarrow$ B4 = "operation phase"!L19! } & Total $C^{\mathrm{MR}} \longrightarrow{ }_{1}^{\top} \mathrm{C} \overline{4}=$ "operation phase"! $\mathrm{L} 20$ \\
\hline 5 & & & Total $C^{E} \longrightarrow{ }_{1}^{C} \mathrm{C} 5=$ "operation phase"!L21! \\
\hline 6 & Disposal & Total EQ ${ }^{\mathrm{ED}} \longrightarrow \mathrm{B} 6=$ "disposal phase"!Y 16 & Total $C^{D} \longrightarrow$ C6 = "disposal phase"!Y17! \\
\hline 7 & SUM & Total emission quantity $\longrightarrow \mathrm{B} 7=\overline{\mathrm{S}} \mathrm{U} \mathrm{M}(\mathrm{B} 2: \mathrm{B} 6)$ & Total costs $\longrightarrow \mathrm{C} 7=\mathrm{SUM}(\mathrm{C} 2: \mathrm{C} 6)$ \\
\hline
\end{tabular}

FIgURE 4: Summary worksheet for LCA and LCC analysis.

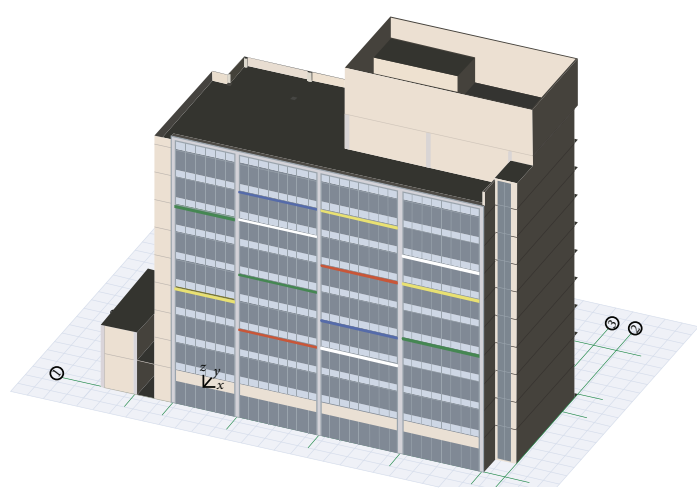

Original model and alternative model 2

(a)

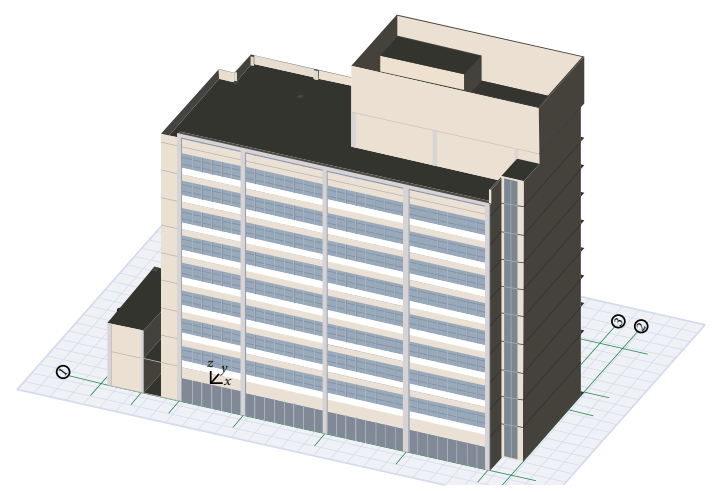

Alternative model 1

(b)

FIGURE 5: Results of BIM for each alternative.

(iii) Type: office building.

(iv) Stories and floor area: 11 stories (one story below ground and 10 stories above ground), a building area of $881.68 \mathrm{~m}^{2}$, and a gross floor area of $7,105.94 \mathrm{~m}^{2}$.

Because it is important to obtain a large volume of data to conduct the LCA and LCCA for the entire building, the application of the developed framework was designed to focus only on the external skin of a building. In addition, the LCA and LCCA were conducted with particular focus on the construction and operation phases. Because the external skin of a building plays an important role in achieving energy efficiency, it has a remarkable effect on the results of the LCA and LCCA. Consequently, among the various alternatives for the skin of a building, it is possible to select the most valuable skin system based on the LCA and LCCA results, if the developed framework is used. In this study, the authors considered three alternatives for the external skin system, including the original external skin system. The following descriptions give an overview of each alternative:

(i) Original skin system: $22 \mathrm{~mm}$ double-glazed curtain wall ( $5 \mathrm{~mm}$ glass $+12 \mathrm{~mm}$ air layer $+5 \mathrm{~mm}$ glass) with a thermal transmittance of $2.79 \mathrm{~W} / \mathrm{m}^{3} \mathrm{~K}$. (ii) Alternative 1: cement brick wall with double-glazed windows ( $5 \mathrm{~mm}$ glass $+6-\mathrm{mm}$ air layer $+5 \mathrm{~mm}$ glass) with a thermal transmittance of $3.25 \mathrm{~W} / \mathrm{m}^{3} \mathrm{~K}$.

(iii) Alternative 2: $24 \mathrm{~mm}$ low-E glass curtain wall $(6 \mathrm{~mm}$ glass $+12 \mathrm{~mm}$ argon layer $+6 \mathrm{~mm}$ low-E glass) with a thermal transmittance of $1.80 \mathrm{~W} / \mathrm{m}^{3} \mathrm{~K}$.

5.1. Modeling and Data Acquisition. The modeling of the building was performed using the "ArchiCAD version 15" software in the following order: (i) creation of site, (ii) creation of structural columns, (iii) creation of bearing wall, and (iv) creation of the slab. After one story was completed, copy and paste commands, along with the grid system function, were used to complete the modeling of the floors (up to the 10th floor). Next, the modeling of the external skin system for each alternative was performed before entering the attribute information. The time required was approximately $12 \mathrm{~h}$.

Figure 5 presents the completed 3D building information model. As mentioned, the modeling of the internal space was excluded from this case study because the purpose of the case application was to conduct the LCA and LCCA for each alternative external skin system. According to several previous studies, the skin system of a building critically affects its thermal conductivity performance. Consequently, the skin system could be regarded as one of the most important 
TABLE 2: Quantity and energy data obtained by BIM.

\begin{tabular}{|c|c|c|c|c|c|}
\hline \multicolumn{3}{|c|}{ Type of data from BIM } & \multicolumn{3}{|c|}{ Properties of each alternative } \\
\hline & & & Original skin & Alt. 1 & Alt. 2 \\
\hline \multirow{14}{*}{ Quantity data } & \multirow{2}{*}{ Aluminum frame } & Volume $\left(\mathrm{m}^{3}\right)$ & 20.96 & 18.53 & 20.96 \\
\hline & & Weight (kg) & 56,815 & 50,213 & 56,815 \\
\hline & \multirow{2}{*}{ Glass } & Volume $\left(\mathrm{m}^{3}\right)$ & 10.64 & 19.38 & 12.77 \\
\hline & & Weight (kg) & 25,321 & 46,123 & 30,385 \\
\hline & \multirow{2}{*}{ Cement brick } & Volume $\left(\mathrm{m}^{3}\right)$ & - & 68.16 & - \\
\hline & & Weight (kg) & - & 20,264 & - \\
\hline & \multirow{2}{*}{ Mortar } & Volume $\left(\mathrm{m}^{3}\right)$ & - & 6.41 & - \\
\hline & & Weight (kg) & - & 16,020 & - \\
\hline & \multirow{2}{*}{ Polystyrene } & Volume $\left(\mathrm{m}^{3}\right)$ & - & 14.2 & - \\
\hline & & Weight (kg) & - & 426 & - \\
\hline & \multirow{2}{*}{ Concrete } & Volume $\left(\mathrm{m}^{3}\right)$ & - & 31.24 & - \\
\hline & & Weight (kg) & - & 74,976 & - \\
\hline & \multirow{2}{*}{ Argon } & Volume $\left(\mathrm{m}^{3}\right)$ & - & - & 12.77 \\
\hline & & Weight (kg) & - & - & 17.62 \\
\hline \multirow{6}{*}{ Energy amount (MWh/yr) } & \multicolumn{2}{|c|}{ Heating } & 311 & 323 & 308 \\
\hline & \multicolumn{2}{|c|}{ Hot-water supply } & 291 & 291 & 291 \\
\hline & \multicolumn{2}{|c|}{ Air-conditioning } & 2,653 & 2,737 & 2,487 \\
\hline & \multicolumn{2}{|c|}{ Ventilation fan } & 130 & 130 & 130 \\
\hline & \multicolumn{2}{|c|}{ Appliance } & 1,770 & 1,770 & 1,770 \\
\hline & \multicolumn{2}{|c|}{ Total consumption } & 5,155 & 5,251 & 4,986 \\
\hline
\end{tabular}

factors affecting the energy consumption of a building. Therefore, this research was structured to conduct energy simulations based on numerous alternatives for building skin systems, while the other simulation conditions were fixed. As described in step 3, the additional information necessary for calculating the energy consumption during the operation phase was set as follows: (i) location $\left(35^{\circ} 9^{\prime}\right.$ in latitude and $125^{\circ} 54^{\prime}$ in longitude), (ii) bearing angle $\left(340^{\circ}\right)$, (iii) type of use (office building), (iv) climate data: KOR Kwangju_471560_ IWEC [30], and (v) type of air-conditioning and heating system (central system).

Once the modeling was complete, (i) the element function of ArchiCAD was used to retrieve the quantity information for each alternative external skin, and (ii) EcoDesigner, which is an add-on function of ArchiCAD, was used to calculate the energy consumption for each alternative, all of which are listed in Table 2. According to the calculations, alternative 2, in which low-E glass was used, showed the lowest total energy consumption (4,986 MWh/yr).

5.2. Input Data for LCA and LCCA. To conduct the LCA and the LCCA for the three target alternatives, it was important to provide the information needed by the three worksheets (i.e., Figures 1, 2, and 3). For example, Figure 6 shows the input data and results for the worksheet in the construction phase when the original skin system (i.e., normal curtain wall) was used.

As shown in the figure, the information obtained from the BIM provided quantity information on aluminum and glass (i.e., cell (E3) to cell (E6) and cell (N3) to cell (N6) in Figure 6), which are the main materials comprising the original skin system. Second, because (i) three sets of equipment (i.e., aluminum cutter, notching clipper, and painter) were used for manufacturing the aluminum, (ii) they were operated by electricity, and (iii) they manufactured raw aluminum in "length" units; the equipment capacity and fuel requirement were entered into cells (E14) to (E16) and cells (F14) to (F16), respectively. Similarly, the capacity and fuel requirement of the equipment for glass manufacturing were entered, as shown in Figure 6 (i.e., cells (N10) to (N13) and cells (O10) to $(\mathrm{O} 13)$ ). In addition, the capacity and fuel requirement of the vehicles used for construction (i.e., a forklift, tower crane, and loader) were entered into lines 21 to 23, according to their fuel types. Finally, the unit cost of $\$ 179.737 / \mathrm{m}^{2}$ for the curtain wall installation work was entered based on the "Korean Price Information for Construction Work," which is similar to the cost data provided by RS Means in the USA [31].

To calculate the LCA and LCCA during the operation phase, (i) the analysis period used when simultaneously conducting the LCA and LCCA was determined to be 40 years, which was the life span of the reinforced concrete building as stipulated by legislation, and (ii) the discount rate for the LCCA was calculated based on the inflation rate and deposit interest rates over the past 10 years, which were provided by the Bank of Korea.

\section{Results and Discussion}

6.1. LCA and LCCA Results. Table 3 lists and Figure 7 shows the LCA results. As listed in Table 3, when a building is operated for 40 years, among the three alternatives, alternative 2 has the lowest $\mathrm{CO}_{2}$ emission (low-E curtain wall system: $26,389,800 \mathrm{~kg}$ ). The $\mathrm{CO}_{2}$ emission of alternative 2 (i.e., $944,786 \mathrm{~kg}$ ) is the highest among the three alternatives in 
TABLE 3: LCA and LCCA results for each alternative.

\begin{tabular}{|c|c|c|c|c|c|c|}
\hline \multicolumn{4}{|c|}{ Building skin system } & Original skin & Alt. 1 & Alt. 2 \\
\hline \multirow{12}{*}{$\begin{array}{l}\text { LCA results } \\
(\mathrm{kg})\end{array}$} & \multirow{7}{*}{$\begin{array}{l}\mathrm{CO}_{2} \text { emission in } \\
\text { construction phase }\end{array}$} & \multirow{7}{*}{ Manufacturing } & Aluminum frame & 839,987 & 750,011 & 839,987 \\
\hline & & & Glass & 100,432 & 39,121 & 104,346 \\
\hline & & & Cement brick & - & 21,391 & - \\
\hline & & & Mortar & & 16,873 & \\
\hline & & & Polystyrene & & 826 & \\
\hline & & & Concrete & - & 13,231 & - \\
\hline & & & Argon & - & - & 453 \\
\hline & & \multicolumn{2}{|c|}{ Construction } & 940,419 & 841,453 & 944,786 \\
\hline & \multirow{2}{*}{$\begin{array}{l}\mathrm{CO}_{2} \text { emission in } \\
\text { operation phase }\end{array}$} & \multirow{2}{*}{ Energy consumption } & One year $(\mathrm{kg} / \mathrm{yr})$ & 668,310 & 675,572 & 659,745 \\
\hline & & & 40 years $(\mathrm{kg})$ & $26,732,400$ & $27,022,880$ & $26,389,800$ \\
\hline & $\begin{array}{l}\mathrm{CO}_{2} \text { emission in } \\
\text { disposal phase }\end{array}$ & \multicolumn{2}{|c|}{ Disposal (kg) } & 21 & 104 & 22 \\
\hline & \multicolumn{3}{|c|}{ Total amount of $\mathrm{CO}_{2}$ emission } & $27,672,400(\mathrm{~kg})$ & $27,864,438(\mathrm{~kg})$ & $26,389,800(\mathrm{~kg})$ \\
\hline \multirow{5}{*}{$\begin{array}{l}\text { LCCA results } \\
\text { (US \$) }\end{array}$} & Construction phase & Initial investr & ment costs & 191,220 & 196,924 & 223,988 \\
\hline & \multirow{2}{*}{ Operation phase } & \multicolumn{2}{|c|}{ Replacement and maintenance costs } & 136,765 & 132,938 & 160,201 \\
\hline & & \multicolumn{2}{|c|}{ Energy costs } & $8,204,352$ & $8,359,094$ & $7,935,464$ \\
\hline & Disposal phase & \multicolumn{2}{|c|}{ Disposal costs } & 9,565 & 14,507 & 10,154 \\
\hline & \multicolumn{3}{|c|}{ Total amount costs } & $\$ 8,541,902$ & $\$ 8,703,462$ & $\$ 8,329,808$ \\
\hline
\end{tabular}

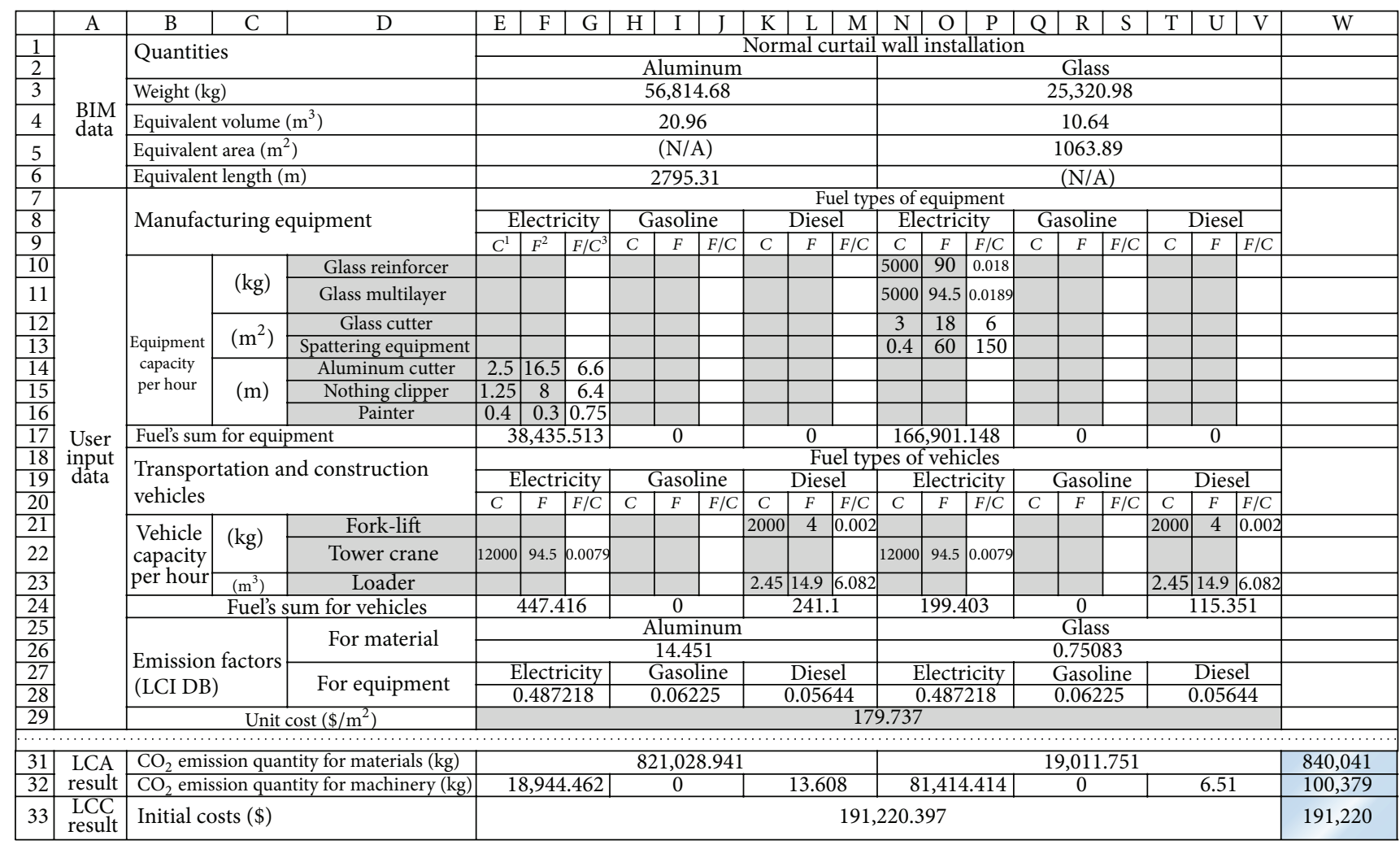

$C^{1}=$ capacity per one cycle

$F^{2}=$ fuel value for the capacity

$F / C^{3}=$ resource per unit capacity

FIgURE 6: Example of application of worksheet for construction phase. 


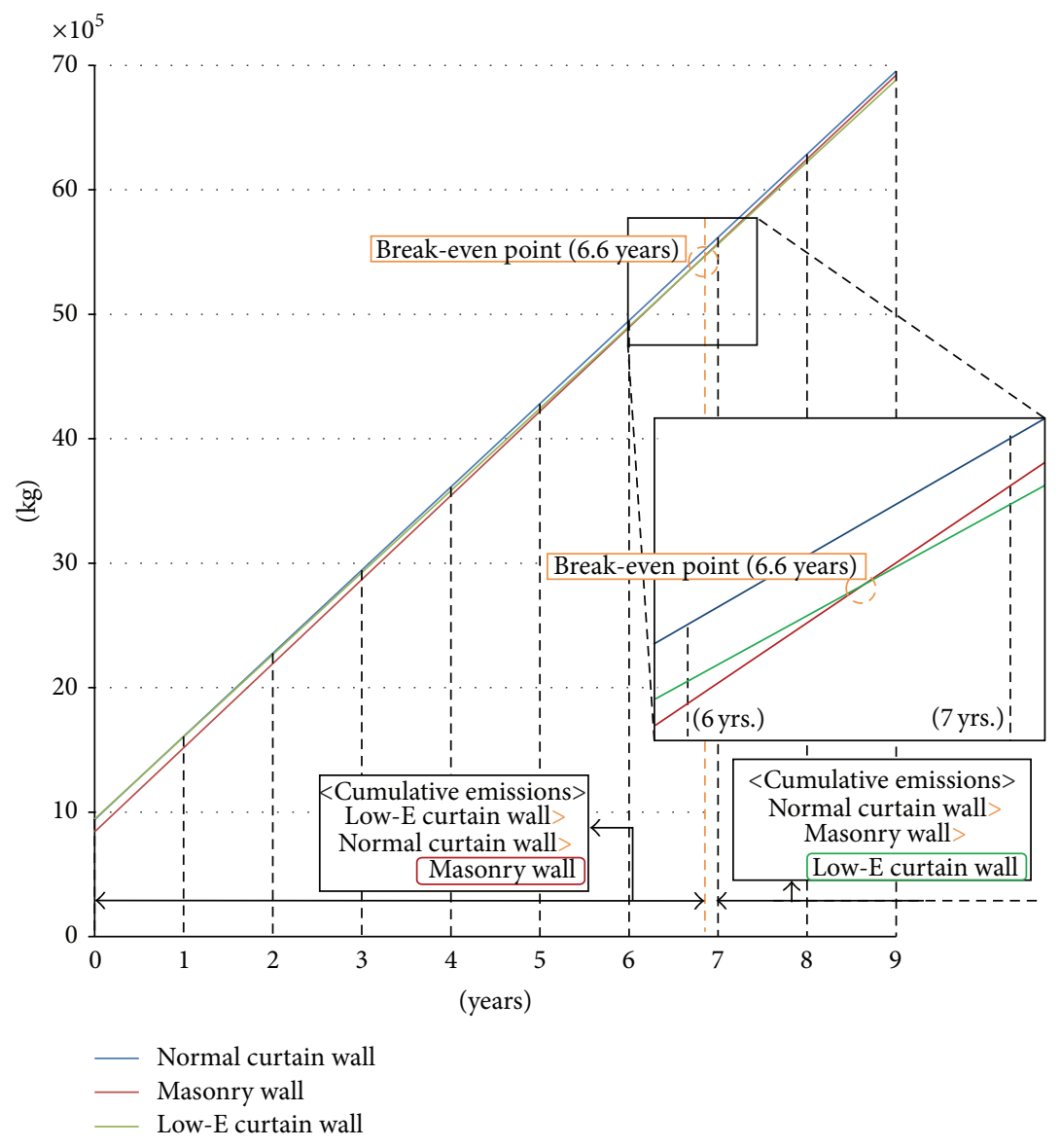

FIGURE 7: Results for accumulating LCA amount over years.

the construction phase but the lowest $(659,745 \mathrm{~kg} / \mathrm{yr})$ in the operation phase. Therefore, alternative 2 was found to have the lowest total amount of $\mathrm{CO}_{2}$ emissions. Figure 7 shows the cumulative $\mathrm{CO}_{2}$ emissions over the operation time.

This alternative (low-E curtain wall system) can be considered to be the most environmentally friendly alternative after 8 years.

In addition, Table 3 lists and Figure 8 shows the LCCA results. As listed in Table 3, when the building is operated for 40 years, among the three alternatives, alternative 2 is the most economical (low-E curtain wall system: $\$ 8,329,808$ ). The initial investment cost of alternative 2 is the highest $(\$ 223,988)$ among the three alternatives, whereas the energy cost of alternative 2 is the lowest $(\$ 7,935,464)$. Therefore, alternative 2 was found to be the most economical in terms of the total amount cost. As shown in Figure 8, which depicts the cumulative LCC over the operation time, alternative 2 can be considered to be the most advantageous alternative in terms of the cost at the time point of 3.4 years because the energy cost is the lowest.

6.2. Advantages and Disadvantages of Applying BIM Technique to Conduct LCA and LCCA. Given the recent trends in the construction industry, which place emphasis on the economic and environmental performance, LCCA and LCA have been widely used. However, their implementation has been a great burden to engineers and project managers. The application of the results of this study will be useful in resolving such problems. In the case application results, it took approximately 12 hours to perform the BIM for the three alternatives for the external skin system, and the model provided information on the material quantities required and energy consumed, which are key items of information for conducting LCA and LCCA. The methodology suggested in this paper can be used to obtain LCA and LCCA results in an efficient manner.

The BIM made it possible to obtain the results of the quantity calculation immediately, and it is compatible with other software because commercial BIM programs can provide their results as Excel spreadsheet. Because various design documents are used to conduct the existing twodimension-based quantity calculations, a large amount of time is required, and errors occasionally result. On the other hand, because the BIM can provide relevant information immediately, it is possible to save time in the early phase of the construction project and obtain more accurate quantity information. In addition, it is important to analyze the energy consumption that is required in the operation phase, wherein the LCA and the LCCA are conducted, which requires considerable time and effort. The energy evaluation function of 


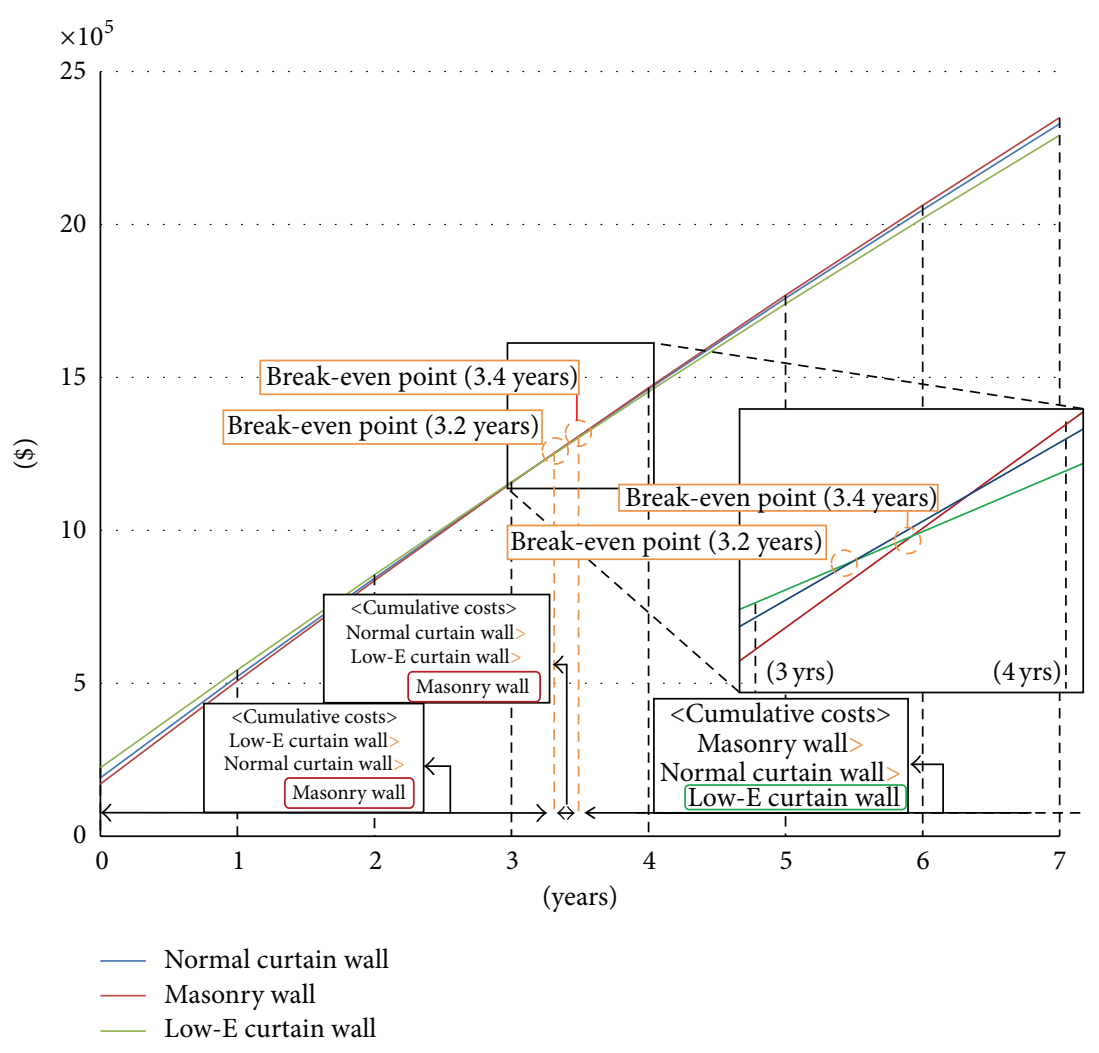

FIGURE 8: Results for accumulating LCC amount over years.

the BIM facilitates calculations of the energy consumption considering the environmental effects.

It is necessary to calculate the fuel consumption for a diverse range of machineries when the LCA is conducted. On the other hand, it is still a burden for engineers to analyze such requirements, because no information on the machinery can be gathered from the BIM results. The information related to machinery can be supported by COBIE spreadsheets [32]. In addition, for a quantity surveying task, it is common to use a margin to make the results of the task more adjustable, whereas there is no margin for the quantity calculation results provided by BIM. Therefore, it is important to add such a function to the BIM tool to make it possible to conduct the LCA and LCCA in a more accurate way. Finally, it is necessary to have macro or library functions as add-ons that allow for LCA and LCCA for the BIM in the future. In other words, if the macro or library functions, which can create the required data automatically, were added to the developed framework, it would be possible to conveniently gather the diverse data necessary for implementing the framework.

\section{Conclusions}

This study evaluated the usability of BIM to conduct LCA and LCCA in the early phase of a construction project. To accomplish this, (i) the methodology and information needed to conduct the LCA and LCCA were analyzed, (ii) mapping between the required information and the information that could be obtained using the BIM was conducted, and (iii) an Excel worksheet-based framework was developed. To identify the usability of the BIM to conduct the LCA and LCCA, a case application was conducted that analyzed three external skin systems for an actual building. Based on the possible diverse alternatives that were considered as a result of the characteristics of the early project phase, the BIM and developed framework could suggest alternatives with better performance in terms of the economic and environmental aspects. Therefore, if the framework developed in this study is applied, it is expected to be suitable for making important decisions in the early phases of a project.

BIM was applied to the framework developed in this study to obtain the quantity information and energy consumption of a project. Consequently, it was insufficient to verify the accuracy of the acquired information. Because the accuracy depended on the performance of the BIM software, this study did not conduct such verification. Rather, a test of the usability of the BIM and framework was performed. In the future, it will be necessary to develop a BIM library to help engineers and project managers gather the required information, including the LCI DB, to conduct the LCA and LCCA.

\section{Conflict of Interests}

The authors declare that there is no conflict of interests regarding the publication of this paper. 


\section{Acknowledgment}

This study was supported by the Basic Science Research Program funded by the Ministry of Education, Science, and Technology (nos. 2014044260 and NRF2014R1A1A1004766).

\section{References}

[1] E. P. Karan and J. Irizarry, "Extending BIM interoperability to preconstruction operations using geospatial analyses and semantic web services," Automation in Construction, vol. 53, pp. $1-12,2015$.

[2] W. Li, J. Zhu, and Z. Zhu, "The energy-saving benefit evaluation methods of the grid construction project based on life cycle cost theory," Energy Procedia, vol. 17, pp. 227-232, 2012.

[3] T. Hong, C. Ji, and H. Park, "Integrated model for assessing the cost and $\mathrm{CO}_{2}$ emission (IMACC) for sustainable structural design in ready-mix concrete," Journal of Environmental Management, vol. 103, pp. 1-8, 2012.

[4] G. Zheng, Y. Jing, H. Huang, X. Zhang, and Y. Gao, "Application of life cycle assessment (LCA) and extenics theory for building energy conservation assessment," Energy, vol. 34, no. 11, pp. 1870-1879, 2009.

[5] Y. Huang, R. Bird, and O. Heidrich, "Development of a life cycle assessment tool for construction and maintenance of asphalt pavements," Journal of Cleaner Production, vol. 17, no. 2, pp. 283296, 2009.

[6] C. Scheuer, G. A. Keoleian, and P. Reppe, "Life cycle energy and environmental performance of a new university building: modeling challenges and design implications," Energy and Buildings, vol. 35, no. 10, pp. 1049-1064, 2003.

[7] I. Z. Bribián, A. A. Usón, and S. Scarpellini, "Life cycle assessment in buildings: state-of-the-art and simplified LCA methodology as a complement for building certification," Building and Environment, vol. 44, no. 12, pp. 2510-2520, 2009.

[8] R. J. Cole, "Energy and greenhouse gas emissions associated with the construction of alternative structural systems," Building and Environment, vol. 34, no. 3, pp. 335-348, 1998.

[9] ISO, ISO 14040, Life Cycle Assessment (LCA)_Principles and Guidelines, Part 1.3, 97, International Organization for Standardization, 2008.

[10] T. Hong, J. Kim, and C. Koo, "LCC and $\mathrm{LCCO}_{2}$ analysis of green roofs in elementary schools with energy saving measures," Energy and Buildings, vol. 45, pp. 229-239, 2012.

[11] F. I. Khan, R. Sadiq, and T. Husain, "GreenPro-I: a risk-based life cycle assessment and decision-making methodology for process plant design," Environmental Modelling and Software, vol. 17, no. 8, pp. 669-692, 2002.

[12] S. Lee, W. Park, and H. Lee, "Life cycle $\mathrm{CO}_{2}$ assessment method for concrete using $\mathrm{CO}_{2}$ balance and suggestion to decrease $\mathrm{LCCO}_{2}$ of concrete in South-Korean apartment," Energy and Buildings, vol. 58, pp. 93-102, 2013.

[13] A. J. Dell'Isola and S. J. Kirk, Life Cycle Costing for Facilities, Construction Publishers \& Consultants, Kingston, Mass, USA, 2003.

[14] T. Uygunoğlu and A. Keçebaş, "LCC analysis for energy-saving in residential buildings with different types of construction masonry blocks," Energy and Buildings, vol. 43, no. 9, pp. 20772085, 2011.
[15] N. H. Wong, S. F. Tay, R. Wong, C. L. Ong, and A. Sia, "Life cycle cost analysis of rooftop gardens in Singapore," Building and Environment, vol. 38, no. 3, pp. 499-509, 2003.

[16] G. Zhang and W. Wang, "The research of comprehensive evaluation model for thermal power equipment based on life cycle cost," Systems Engineering Procedia, vol. 4, pp. 68-78, 2012.

[17] N.-B. Chang, B. J. Rivera, and M. P. Wanielista, "Optimal design for water conservation and energy savings using green roofs in a green building under mixed uncertainties," Journal of Cleaner Production, vol. 19, no. 11, pp. 1180-1188, 2011.

[18] P. O. Akadiri, P. O. Olomolaiye, and E. A. Chinyio, "Multicriteria evaluation model for the selection of sustainable materials for building projects," Automation in Construction, vol. 30, pp. 113-125, 2013.

[19] F. Fu, H. Luo, H. Zhong, and A. Hill, "Development of a carbon emission calculations system for optimizing building plan based on the LCA framework," Mathematical Problems in Engineering, vol. 2014, Article ID 653849, 13 pages, 2014.

[20] National Institute of Building Sciences, Building SMART Alliance Strategic Goals, National Institute of Building Sciences, 2007, http://www.nibs.org/?page=bsa.

[21] GSA, GSA BIM Guide Overview, US General Services Administration, Washington, DC, USA, 2007.

[22] B. Succar, "Building information modelling framework: a research and delivery foundation for industry stakeholders," Automation in Construction, vol. 18, no. 3, pp. 357-375, 2009.

[23] J. Basbagill, F. Flager, M. Lepech, and M. Fischer, "Application of life-cycle assessment to early stage building design for reduced embodied environmental impacts," Building and Environment, vol. 60, pp. 81-92, 2013.

[24] G. Han, J. Srebric, and E. Enache-Pommer, "Variability of optimal solutions for building components based on comprehensive life cycle cost analysis," Energy and Buildings, vol. 79, pp. 223231, 2014.

[25] M. Ristimäki, A. Säynäjoki, J. Heinonen, and S. Junnila, “Combining life cycle costing and life cycle assessment for an analysis of a new residential district energy system design," Energy, vol. 63, pp. 168-179, 2013.

[26] C. R. Iddon and S. K. Firth, "Embodied and operational energy for new-build housing: a case study of construction methods in the UK," Energy and Buildings, vol. 67, pp. 479-488, 2013.

[27] Korea Life Cycle Inventory (LCI) Database, "LCI Database," 2015, http://www.edp.or.kr/lci/lci.asp.

[28] S. Tae, S. Shin, J. Woo, and S. Roh, "The development of apartment house life cycle $\mathrm{CO}_{2}$ simple assessment system using standard apartment houses of South Korea," Renewable and Sustainable Energy Reviews, vol. 15, no. 3, pp. 1454-1467, 2011.

[29] BuildingSMART KOREA, Overview of BIM-Definition of BIM, BuildingSMART KOREA, 2015, http://www.buildingsmart.or .kr/overview/BIM.aspx.

[30] American Society of Heating and Refrigerating and Air-Conditioning Engineers, "Resources \& Publications-International Weather for Energy Calculations," 2013, http://www.ashrae.org/ resources-publications/bookstore/climate-data-center\#iwec.

[31] Korea Price Information, 2013, http://www.kpi.or.kr.

[32] W. East, COBIE (Construction-Operations Building Information Exchange), US Army Engineer Research and Development Center, US Army Corps of Engineers, Washington, DC, USA, 2007. 


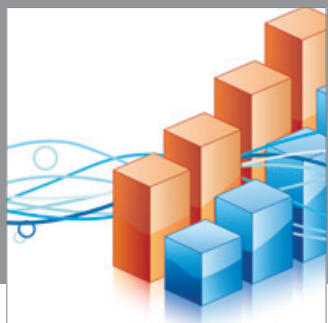

Advances in

Operations Research

mansans

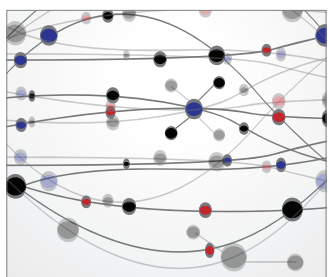

The Scientific World Journal
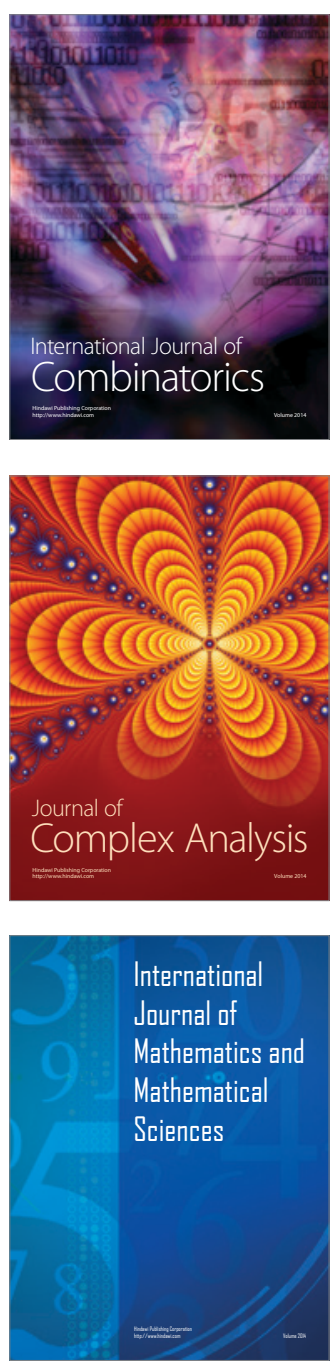
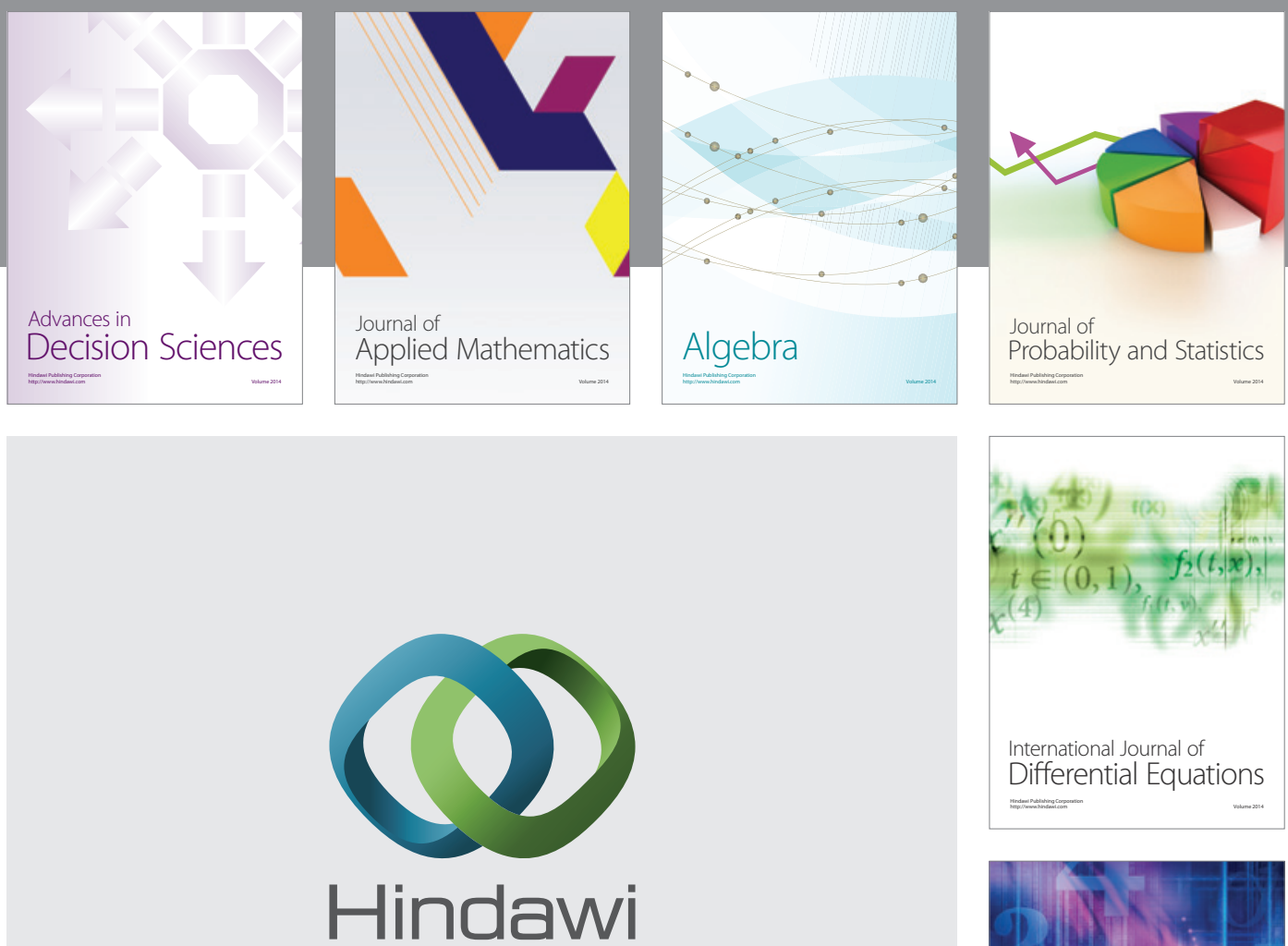

Submit your manuscripts at http://www.hindawi.com
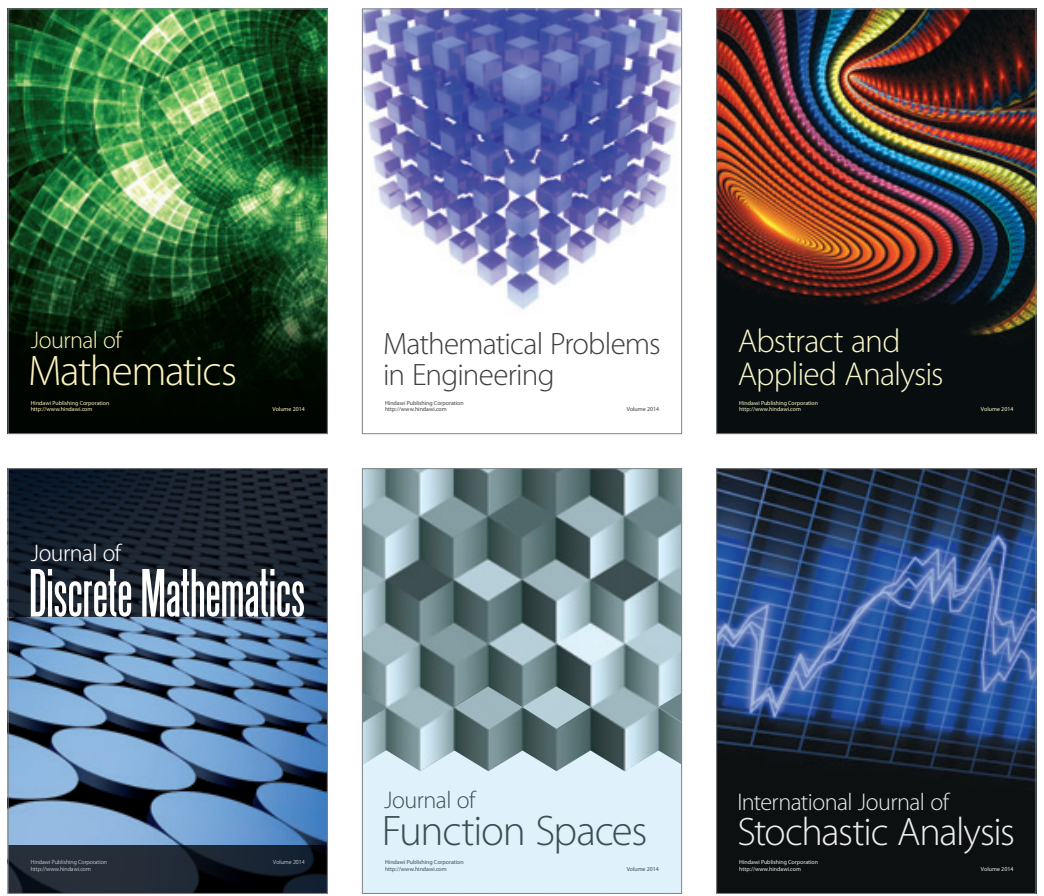

Journal of

Function Spaces

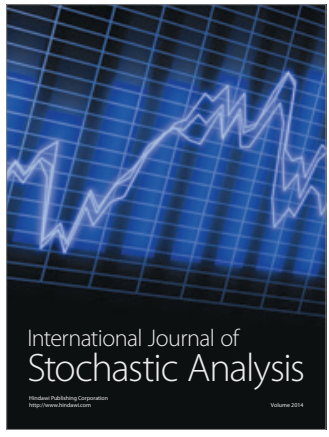

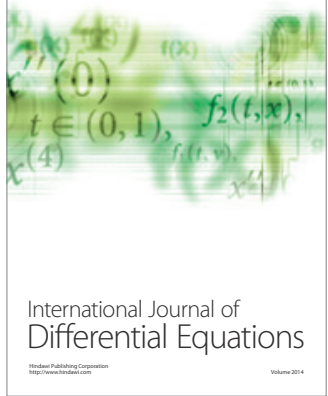
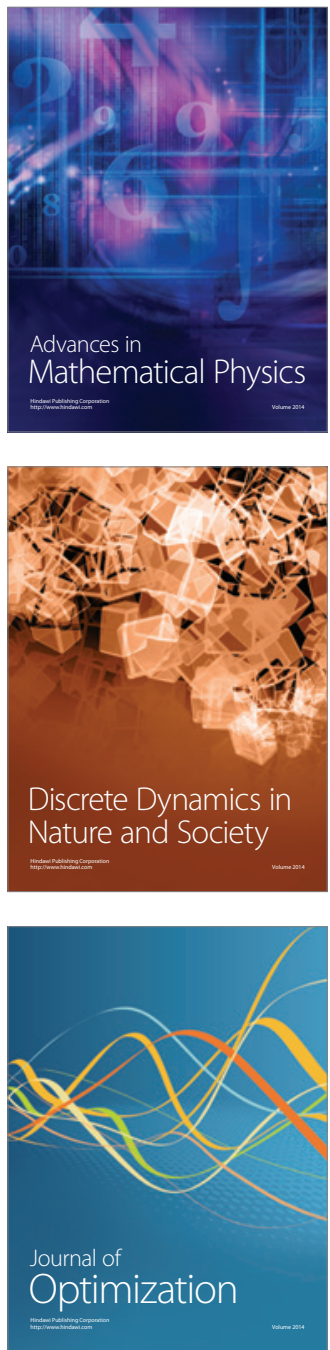